\title{
Mirja Tolkki-Nikkonen
}

\section{Yksilön elämänkaaren kriittiset vaiheet}

Tolkki-Nikkonen, Mirja. 1983. Yksilön elämänkaaren kriittiset vaiheet. Aikuiskasvatus 3, 1, 18-21. - Artikkelissa tarkastellaan ihmisen elämäntapahtumaan, aikuisuuteen ja ikään vaikuttavia tekijöitä sekä sitä, miten ihmiset kokevat elämänkäännekohtia, kriisivaiheita. Persoonallisuuden kehitysprosessin todetaan olevan aina yksilöllinen ja ainutlaatuinen tapahtuma.

"'On kammottavaa ajatella, että elämämme on kertomus vailla juonta ja sankaria" (Osip Mandelstam). Yhtä kammottavaa on ajatella, ettei tässä jutussa ole mitään juonta, vaikka sen pitäisi olla seuraava: Yksilön elämänkaareen vaikuttavat yhteiskunnalliset ja historialliset tekijät ja vaikka ihmisten elämässä olisi sattunut samoja asioita, niiden merkitys on heille erilainen.

\section{Ikä, sosiaalinen ja historiallinen aika}

Ihmisen elämä kuvataan usein eräänlaisena kaarena: fyysisten, psyykkisten ja sosiaalisten voimavarojen kasvuna, huippuna ja heikentymisenä. Elämänvaiheet voidaan karkeasti peri- odisoida lapsuuteen, nuoruuteen, aikuisuuteen ja vanhuuteen. Ikä sinänsä ei kuitenkaan selitä elämän eri vaiheita. Ajatellaan vaikkapa aikuistumista, jota voidaan tarkastella fyysiseltä ja psykologiselta kannalta eli onko biologisesti tai psyykkisesti kypsä, sekä kognitiiviselta ja sosiaaliselta kannalta eli miten vanhaksi itsensä tuntee ja onko saavuttanut tietyt sosiaaliset rajapyykit. Eri kriteerien mukaan aikuisuuden ikä vaihtelee. Puberteetin jälkeen sosiaalisilla tekijöillä on keskeinen rooli kehityksellisten muutosten säätelyssä. Esimerkiksi 20-vuotias taloudellisesti riippumaton ansiotyössä käyvä voi olla "'kehityksellisesti" vanhempi kuin samanikäinen opiskelija, joka asuu vanhempiensa luona. Mutta jos opiskelija on naimisissa, on aikuisuuden määrittely ongelmallisempaa. 
Aikuisuuden sosiaalisiksi rajapyykeiksi usein mainitaan kotoa lähtö, avioituminen, lapsen syntyminen ja työelämään siirtyminen. Nämä rajapyykit saavutettuaan ihminen saattaa kokea, että nyt sitten täytyy olla aikuinen. Eräs 19-vuotiaana avioitunut mies totesikin 10 vuotta jälkeenpäin: "'Oli niin erilainen silloin, fossiili, vanhempi kuin nyt, suhtautui elämään haudanvakavasti. Muutti pois kotoa, tuli jonkinlainen rooli päälle, tässä sitä ollaan naimisissa oleva mies, pitäis yrittää, tässä elämässä pyrkiä, potkia eteenpäin".

Aikuisuuteen siirtyminen on viime vuosisataan verrattuna ajallisesti pidentynyt $\mathrm{mm}$. siksi, että koulua käydään pidempään ja työelämään siirrytään myöhempään. On myös esitetty, että viime vuosisadalla siirtyminen lapsuudesta aikuisuuteen ja aikuisuudesta vanhuuteen olivat vähemmän jyrkkiä kuin nykyisin, mikä saattoi helpottaa yksilön elämänkulussa jatkuvuuden tunnetta.

Ikä on kuitenkin siinä mielessä keskeinen, että ikävaiheisiin liittyy sosiaalisia aikatauluja siitä, milloin ja missä järjestyksessä eri elämäntapahtumat etenevät. Kaiken voi tehdä "ajallaan", liian "aikaisin" tai liian "myöhään'’. On aika siirtyä työelämään, avioitua, hankkia lapsia, siirtyä eläkkeelle ja jopa aika sairastua ja kuolla. Neugartenin termiä käyttääkseni sosiaalinen kello on ajoituksen päälähteitä säädellessään yksilön elämänkulkua ikään liittyvien rajapyykkien ja tapahtumien läpi (Kimmel 1974, 67). Tämän ilmiön tuottavat ikänormit (millainen käyttäytyminen missäkin iässä on sopivaa), ikärajoitukset (mm. oppivelvollisuuslaki, lapsityövoiman käytön kieltäminen, täysi-ikäisyys-, avioliiton solmimis- ja eläkkeelle siirtymisikä), ikästatussysteemi ja ikään liittyvät roolit. Kysymys on itse asiassa siitä, kuinka ihmisten tulisi tässä yhteiskunnassa elää.

Siitä, havaitsevatko ihmiset sosiaalista painetta noudattaa aikatauluja on saatu hieman ristiriitaisia tuloksia. Joidenkin tutkimustulosten perusteella näyttää siltä, ettei painetta havaita ja toisten perusteella siltä, että ihmiset ovat tietoisia normeista ja paineesta, mutta he eivät välitä niistä. Ryder $(1974,77)$ puolestaan on väittänyt, että sosiaaliset aikataulut ovat niin syvällä elämässämme, että ne katoavat näkymättömiin, mikä on yksi niiden voiman päälähteistä. Toisaalta on havaittu, että elämäntapahtumien järjestys on tällä vuosisadalla tullut vapaavalintaisemmaksi ja nuoret eivät havaitse ikänormeja yhtä tiukasti kuin vanhemmat ihmiset (Kimmel 1974, 67).

Elämäntapahtumien ajoitus joka tapaukșes- sa vaihtelee eri yhteiskuntaluokissa ja eri historiallisina aikoina. Amerikkalaisissa tutkimuksissa on mm. havaittu, että työväestöön kuuluvat ajoittavat keski-iän ja vanhuuden aikaisemmaksi kuin keskiluokka. Työväestö näkee myös varhaisaikuisuuden vakiintumisen ja keskiluokka kokeilujen kaudeksi. Työväestöllä elämänkaari etenee jossain määrin nopeammassa tahdissa kuin ylempiin yhteiskuntaluokkiin kuuluvilla, sillä mitä korkeampi yhteiskuntaluokka sitä myöhempään ikävaiheeseen ajoittuvat koulunkäynnin lopettaminen, työelämään siirtyminen, avioliiton solmiminen, lasten hankinta, isovanhemmuus ja työuran huippu (Neugarten 1968, 144-145).

Tietyissä olosuhteissa saattaa tosin olla vaikeaa elää kulttuurin normien mukaan, vaikka normit hyväksyisikin, koska ei ole resursseja noudattaa niitä. Vaikkapa lamakausi vakaan taloudellisen kasvun vaiheeseen verrattuna saattaa aiheuttaa muutoksia avioliiton solmimisessa ja ajoituksessa, lasten hankinnassa, opiskelussa ja tietenkin työllisyydessä ja nämä muutokset ovat erilaisia eri yhteiskuntaluokissa. Elämänkaaren mallit ja sosiaaliset aikataulut ovatkin erilaisia eri historiallisina aikoina. Ihmiset elävät, kehittyvät ja muuttuvat eri aikoina ja yhteiskunnan muutoksesta seuraa myös elämänkaaren mallien ja tärkeiden käännekohtien muuttuminen. Eri ikäluokilla, sukupolvilla on ollut erilaiset kehitysedellytykset ja elämänkulun reittien valinnan vapausaste on ollut erilainen. Viime vuosisadalla saattoi kolmekin sukupolvea elää suhteellisen samankaltaisessa muuttumattomassa yhteiskunnassa, jolloin sukupolvien välinen kuilukin lienee ollut pienempi. Sen sijaan tällä vuosisadalla syntyneet eri sukupolvet ovat eläneet täysin erilaisissa maailmoissa. Vuosisadan alkupuolella syntyneet ovat 1950 -luvulla syntyneisiin verrattuna kokeneet kolme sotaa, lamakauden, yleislakon, avaruuden valloituksen, atomipommin keksimisen jne. Ikä onkin sijoitettava historialliseen yhteyteen. On aivan eri asia olla nuori esimerkiksi 1940-luvulla kuin 1980-luvulla. Myös samalla historiallisella tapahtumalla esimerkiksi II maailmansodalla tai muuttoliikkeellä - voi olla hyvin erilainen merkitys riippuen siitä, missä elämänvaiheessa yksilö on (esim. nuori mies, äiti, lapsi).

\section{Elämän käännekohdat}

Elämänkulussa on tiettyjä kriisivaiheita, käännekohtia, joiden jälkeen muutos on välttämätön. Mutta minkä muutos? Mikä ihmisessä muuttuu? Leontjevin analyysiin perustuen voi vastata, että toiminta ja sen muuttuessa 
myös persoonallisuus, jonka nimenomaan toiminta synnyttää. Leontjevin teoriassa motiivien hierarkian muoto on persoonallisuuden yksi parametri. Elämänkriiseissä on kysymys ennen kaikkea motivaatiorakenteen muuttumisesta. Motiivien hierarkia muuttuu, syntyy uusia motiiveja ja samalla uusia toimintalajeja. Elämänprosessi onkin toimintojen kokonaisuus tai tarkemmin ilmaistuna vaihtuvien toimintojen järjestelmä.

Se todellinen kenttä, joka määrää ihmisen teot ei ole pelkästään fyysisesti läsnäoleva, mutta se on olemassa oleva vaikkapa vain illusorisesti. Yksilön tieto tästä olemassa olevasta edeltää aina sen muuttumista toiminnan määrittäjäksi. Todellisuus on myös olemassa ihmisen menneisyytenä ja hänen ennakoimanaan tulevaisuutena. Aikaisemmat vaikutelmat, tapahtumat ja teot saattavat vaihtaa panostaan persoonallisuudessa. Jokin aikaisemmasta häviää tai menettää mielensä, jokin toinen seikka menneisyydessä saattaa avautua aivan uudessa valossa tai jokin menneisyyden tapahtuma saatetaan torjua aktiivisesti. Tällaisia muutoksia tapahtuu jatkuvasti, mutta ne voivat myös keskittyä ja saada aikaan murroksen. Muutoksia tuottavat yksilön teot, toisinaan ulkoisetkin, kuten aikaisempien vuorovaikutussuhteiden katkeaminen, ammatin vaihto tai siirtyminen uusiin olosuhteisiin. (Leontjev 1977, 77, 171172, 176-177).

Muutos, siirtymä voidaan määritellä katkoksi ihmisen elämänkaaressa. Sillä on sekä objektiivinen että subjektiivinen merkityksensä. Kulttuurimme määrittelee siirtymiksi mm. kuoleman, syntymän, avioliiton solmimisen, paikkakunnan vaihdon, työpaikan vaihdon. Subjektiivisuus merkitsee yksilön omaa havaintoa tapahtumasta, tietoisuutta katkosta, joka vaatii muutosta joko tilanteen tai vaadittavan käyttäytymisen uutuuden tai molempien vuoksi (Adams et al. 1976. 5-6). Vain osalla ihmisen ympäristön objektiivisista ominaisuuksista on todellista vaikutusta hänen elämäänsä, kehitykseensä ja toimintaansa. Lisäksi on huomattava, että jollakin asialla, jonka objektiivisen merkityksen (esim. sairaus, kuolema) hyvin tiedostaa, ei ehkä tietyssä elämänvaiheessa ole merkitystä, se ei sisälly elämään eikä muuta sitä hiukkaakaan eikä hetkeksikään. Jossakin toisessa elämänvaiheessa sen mieli saattaa muuttua merkityksen pysyessä ennallaan. Elämäntapahtumilla on siis eri yksilöille erilainen persoonallinen mieli.

Tilanteen subjektiivinen arviointi näyttää eräiden sairastavuutta koskeneiden tutkimustulosten mukaan tärkeämmälẗ̈ kuin itse ob- jektiivinen tapahtuma tai tilanne (esim. Thurlow 1970; Vinocur \& Selzer 1975). Yksilön tulkinta jostakin tapahtumasta voi myös riippua sitä seuranneista muista tapahtumista tai hänen senhetkisestä emotionaalisesta tilastaan, ts. kullakin hetkellä menneisyyden eri puolet painottuvat vallitsevan tilanteen mukaan. Usein muutokset huomataan vasta jälkeenpäin. Ne näyttävät erityisiltä kriisikausilta, jotka ovat muodostuneet subjektiiviselle elämiselle käänteentekeviksi elämänkulun kokonaisuuden kannalta.

Elämäntapahtumat ja muutokset ovat eri tavoin ennakoitavissa. Ne voivat olla tarkoituksellisia muutoksia, äkillisiä yllätyksiä tai yksilö voi vähitellen tiedostaa muutoksen. Jostakin tapahtumasta yksilö on itse vastuussa, joitakin muita hän ei pysty kontrolloimaan. Siirtymiä voi myös tarkastella sen perusteella, onko kysymyksessä jonkin saavuttaminen (työhönmeno, ylennys, avioituminen), jolloin täytyy löytää uusi identiteetti vai onko kysymyksessä jonkin menettäminen, jolloin on keskeistä päästä eroon menneestä (Adams et al. 1976). Sosiaalisiin aikatauluihin liittyy se seikka, että tapahtumat sinänsä eivät välttämättä ole kriisiyttäviä. Sitä ovat lähinnä odottamattomat tapahtumat. Esimerkiksi leskeys 25-vuotiaana saatetaan kokea vaikeampana kuin avioero. Useimmissa tapauksissa elämän käännekohdat eivät ole varsinaisia kriisitilanteita, vaan kysymyksessä on normaali siirtymävaihe. Ongelmana on siirtymien ajoitus ja yhteensovittaminen.

Voisi myös olettaa, että erilaiset elämänmuutokset (esim. sairastuminen) kärjistyvät normaaleissa siirtymävaiheissa. On jopa laskettu stressiarvoja elämän eri muutoksille ja arvioitu, kuinka monta muutosta ihminen yhden vuoden kuluessa kestää. Muutoksia ei kyllä ole järkevää vain formaalisti laskea yhteen eikä niiden kasautuminen välttämättä aiheuta kriisiä negatiivisessa mielessä. Tilanteen arviointi (esim. sen uhkaavuus) riippuu myös aikaisemmista kokemuksista vastaavanlaisista tilanteista sekä yksilön psykologisista resursseista (Lazarus 1966). Myös Chiriboga ja Dean (1978) havaitsivat, että jos ihminen pystyy hallitsemaan tilanteen, stressi voi aiheuttaa kasvua eli muutos ei välttämättä ole negatiivinen.

\section{Kriisejä tarvitaan}

Elämä voidaan kaaren sijasta nähdä myös tasaisena viivana, jossa toisinaan on pieni hypähdys - jos on. Hypähdykset eli kriisivaiheet antavat ihmiselle mahdollisuuden kasvuun ja kehitykseen. Kriisiin voi tietenkin myös reagoi- 
da passiivisesti tai taantua sen seurauksena, mutta voi myös toimia aktiivisesti kohdatakseen sen ja nähdä siinä kasvun ja kehityksen mahdollisuuksia. Kehittyäkseen ihmiset tarvitsevat kriisejä, tasapainottomuutta ja jatkumattomuutta.

Se, mitä ihmiset ovat, määräytyy heidän toiminnastaan. Kehityksen myötä toimintojen piiri voi myös köyhtyä eikä ainoastaan laajentua. Yksilön objektiivisten kehitysmahdollisuuksien ja todellisten elämänolosuhteiden ristiriidasta voi olla seurauksena joko persoonallisuuden kehittyminen tai sen estyminen. Selitystä ei ehkä vaadikaan se, miksi ihminen muuttuu ja kehittyy, vaan se, että kehitys voi pysähtyä paikoilleen. Kehitykselliset ilmiöt ovatkin paremmin ja eritellymmin kuvattavissa, kun ne suhteutetaan elämänkaaren aikaisempiin osiin. Esimerkiksi vanhat ihmiset, joilla on passiivinen, "luopunut" elämäntyyli, ovat voineet päätyä siihen eri reittien kautta: toiset ovat todella luopuneet aikaisemmista toiminnoistaan, toisilla elämäntyyli on ollut passiivista aikaisemmissakin elämänvaiheissa.

Yksi mahdollisuus kehitykseen lienee se, ettei noudata sosiaalisia aikatauluja. Ei alistu siihen, että tietyssä elämänvaiheessa täytyy toimia tietyllä tapaa. Tai ajattelee, että jossakin elämänvaiheessa voi todella tehdä jotakin, minkä muut ovat tehneet $10-20$ vuotta nuorempina. Kaiken kaikkiaan näyttäisi olevan niin, että ihminen ei havaitse sosiaalisia aikatauluja silloin, kun hän niitä noudattaa. Ellei niitä noudata, ne hallitsevat koko elämää, sillä yksilö on tällöin poikkeava ja se saattaa pysähdyttää hänet pohtimaan elämäänsä ja mahdollisuuksiaan.

\section{Loppulausahdus}

Yksilön kehitystä voidaan ymmärtää vain muuttuvan henkilön ja hänen muuttuvan ympäristönsä välisen vuorovaikutuksen tuloksena. Persoonallisuuden kehitysprosessi pysyy aina mitä suurimmassa määrin yksilöllisenä ja ainutlaatuisena. Se ei noudata ikäjatkumoa ja kehitys saattaa taantuakin. Se etenee täysin eri tavoin riippuen konkreettisista historiallisista olosuhteista ja yksilön kuulumisesta johonkin sosiaaliseen ympäristöön. Ihminen ei yhteiskunnassa vain kohtaa niitä ulkoisia ehtoja, joihin hänen täytyy toimintansa sopeuttaa, vaan inhimillisen toiminnan motiivit ja tavoitteet riippuvat näistä yhteiskunnallisista ehdoista (Leontjev 1977, 33, 78, 132, 175).

\section{Kirjallisuus}

Adams, J., J. Hayes \& B. Hopson. 1976. Transitions. Understanding and managing personal change. Martin Robertson \& Company: Bath.

Chririboga, D.A. \& H. Dean. Dimensions of stress: perspectives from a longitudinal study. Journal of Psychosomatic Reserarch 22, 1978, 47-55

Edler, G.H. Jr. 1978. Family history and the life course. T.K. Harevan (ed.), Transitions. The family and the life course in historical perspective. Academic Press: New York.

Kimmel, D.C. 1974. Adulthood and aging. An interdisciplinary, developmental view. John Wiley \& Sons, Inc.: New York.

Lazarus, R.S. 1966. Psychological stress and the coping process. McGraw-Hill: New York.

Leontjev, A.N. 1977. Toiminta, tietoisuus, persoonallisuus. Kansankulttuuri. Kuopio.

Neugarten, B.L. 1968. Adult personality: toward a psychology of the life cycle. B.L. Neugarten (ed.). Middle age and aging. A reader in social psychology. The University of Chicago Press: Chicago.

Ryder, N.B. Comment on Robert Willis' economic theory of fertility behavior (ref. Elder 1978).

Thurlow, H.J. Illness in relation to life situation and sick role tendency. Journal of Psychosomatic Research 15, 1970, 73-88.

Vinokur, A. \& M.L. Selzer, Desirable vs. undesirable life events: Their relationship to stress and mental distress. Journal of Personality and Social Psychology 32, 1975, 329-337. 